\title{
Potential Changes in Ground-Water Flow and their Effects on the Ecology and Water Resources of the Cape Cod National Seashore, Massachusetts
}

By John P. Masterson (U.S. Geological Survey) and John W. Portnoy (National Park Service)

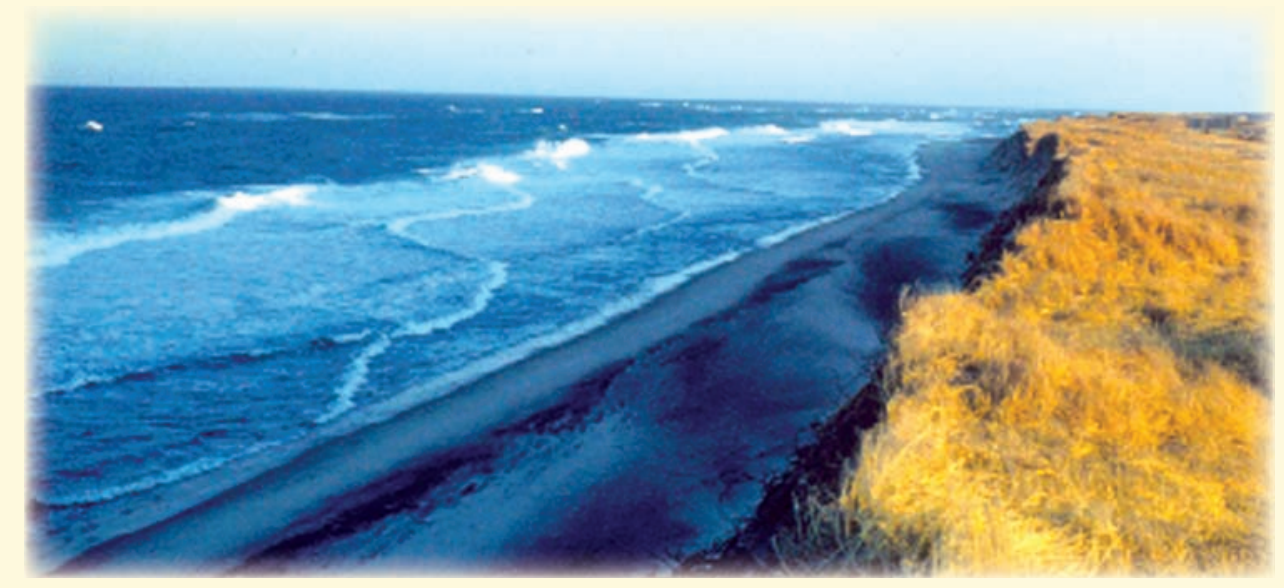

ontinued land development, population growth, and sea-level rise have created concerns regarding $\checkmark$ the supply of potable water and the quality and quantity of fresh ground water discharging to ponds, streams, and coastal areas on Lower Cape Cod, Massachusetts. These potential concerns include:

(1) Increased loading of the nutrients nitrogen and phosphorus, and the consequent eutrophication of fresh and coastal surface-water bodies.

(2) Declines in pond levels, increases in the depth to the water table beneath inland wetlands, reductions in streamflow, reductions in ground-water discharge to the coast, and increased saltwater intrusion from increased ground-water withdrawals.

(3) Increased erosion rates, damage from higher storm-surge flooding, landward intrusion of seawater in coastal marshes and wetlands, and a decrease in the thickness of the freshwater lens from rising sea levels.

Therefore, understanding how ground-water flow affects freshwater and estuarine ecosystems of the Cape Cod National Seashore is vital to managing and protecting these natural resources.

\section{Introduction}

The Cape Cod National Seashore (CCNS), Cape Cod, Massachusetts (fig. 1), is underlain by four lenses of fresh ground water- the Nauset, Chequesset, Pamet, and Pilgrim flow lenses, which are bounded laterally and below by saltwater (figs. 2, 3). These four flow lenses constitute the Lower Cape Cod aquifer system and are the only source of drinking water for the communities of
Eastham, Wellfleet, Truro, and Provincetown, and for the various National Park Service facilities throughout the CCNS. Also, ground-water discharge from these lenses provides the primary source of water for the numerous kettle-hole ponds, streams, and wetlands throughout Lower Cape Cod. This discharge also helps to maintain the biological diversity and productivity of estuaries and salt marshes. 


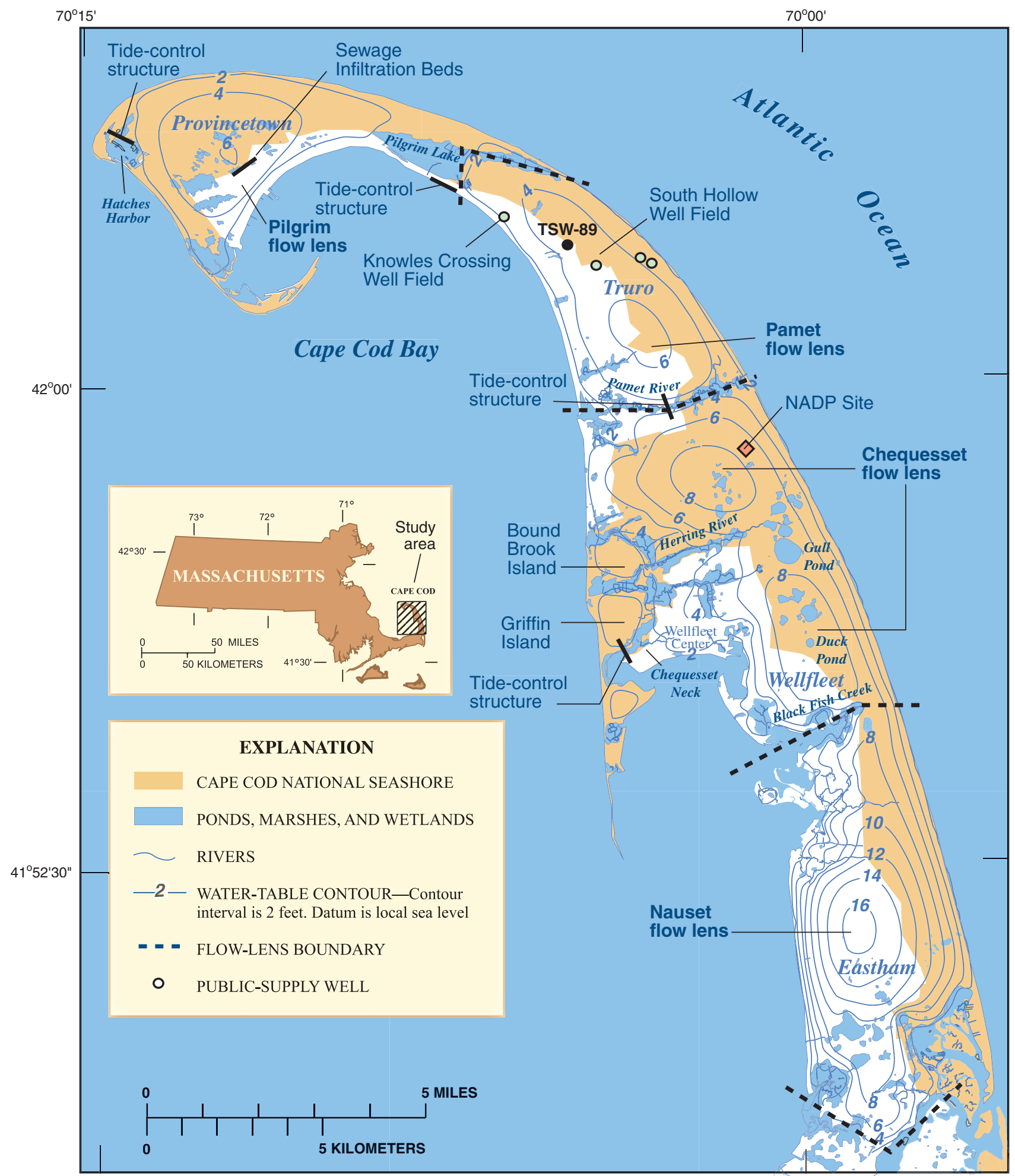

Base from U.S. Geological Survey Digital Line Graphs, and topographic quadrangles, Provincetown, Wellfleet, and Orleans, Massachusetts, 1:25,000, Polyconic projection, NAD 1927, Zone 19

Figure 1. The Lower Cape Cod aquifer system in Cape Cod, Massachusetts, is composed of four flow lenses, as shown by the water-table contours. Ground water flows from the centers of the water-table mounds toward the coast. 


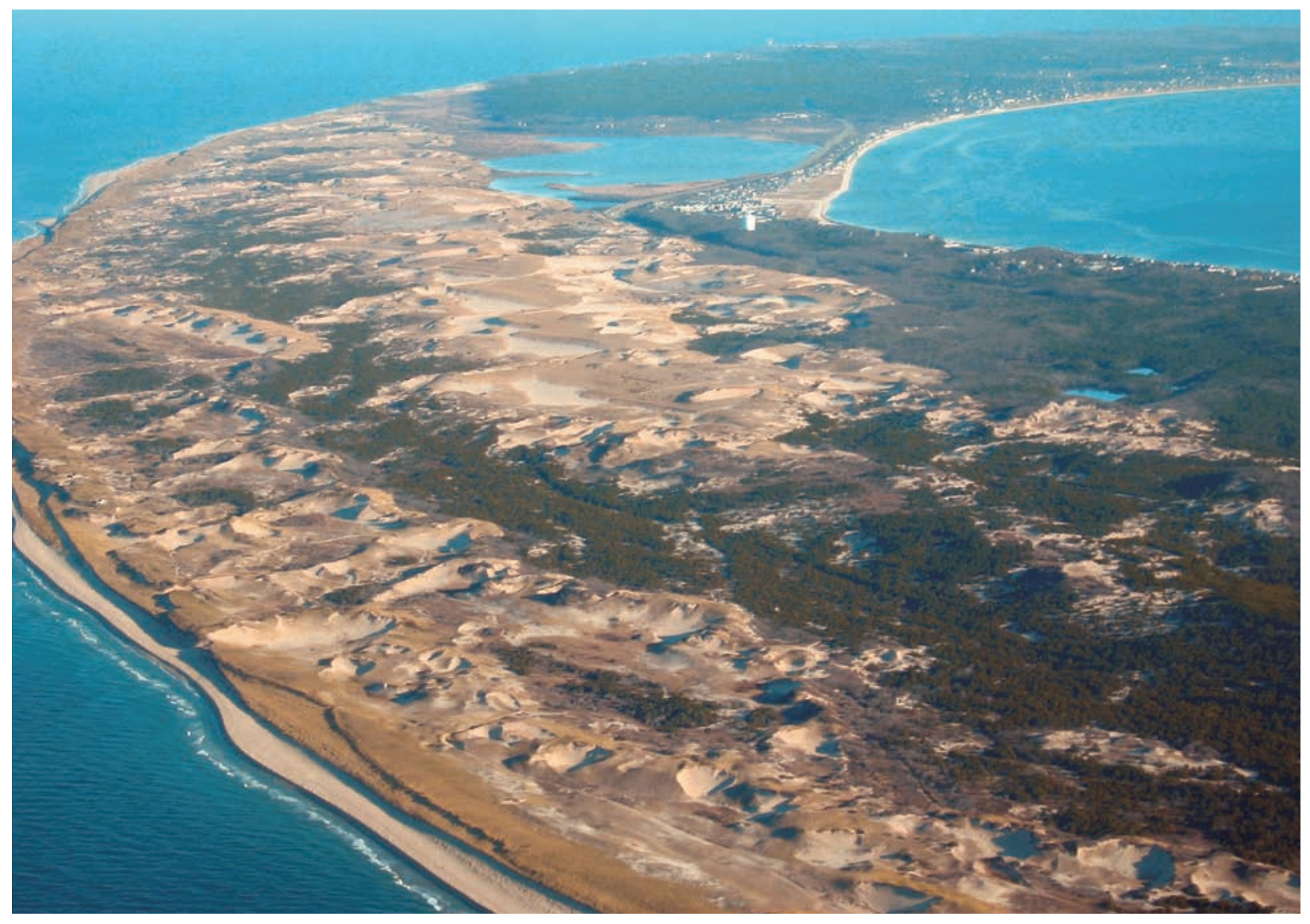

Figure 2. The Pilgrim flow lens, like the other flow lenses of the Lower Cape Cod aquifer system, is bounded laterally by the Atlantic Ocean and Cape Cod Bay. Rainfall that reaches the water table as recharge eventually leaves the aquifer system as ground-water discharge along the coast. View looking southeast.

As land development and water demand increase, and as wastewater continues to be returned to the aquifer system through onsite septic systems, environmental managers are becoming concerned about possible long-term effects of these activities on the Lower Cape Cod aquifer system. In response to these concerns, the USGS, in cooperation with the National Park Service (NPS), Massachusetts Executive Office of Environmental Affairs, Cape Cod Commission, and the Towns of Eastham, Provincetown, Truro, and Wellfleet, began an investigation in 2000 to improve the understanding of the hydrogeology of the Lower Cape Cod aquifer system and to assess possible hydrologic effects of proposed water-management strategies.

This report provides a brief overview of the hydrogeology of the Lower Cape Cod aquifer system and the importance of ground-water levels and flow to the ecology of the Cape Cod National Seashore freshwater and estuarine ecosystems. Also, the report includes a discussion of the implications of future changes to the ground-water system and their effects on ecosystems and water resources of Lower Cape Cod.
For a more detailed description and analysis of groundwater flow in the Lower Cape Cod aquifer system, refer to U.S. Geological Survey (USGS) Scientific Investigations Report 2004-5014 (Masterson, 2004).

\section{Hydrogeology of Lower Cape Cod}

The Lower Cape Cod aquifer system is composed of glacially deposited sediments that range in size from clay to boulders. Approximately 15,000 years ago, glacial ice sheets covered much of New England and extended north and east of present-day Lower Cape Cod (Oldale, 1992). Meltwater from these glaciers carried sediments that were originally trapped in the ice, and deposited them in large deltas in adjacent Glacial Lake Cape Cod, the present-day Cape Cod Bay. At that time, global sea levels were lower than current levels because of the large quantity of water contained in the enormous ice sheets. As the ice sheets melted and retreated, sea level rose, and erosion of the glacial Cape Cod shoreline began. 


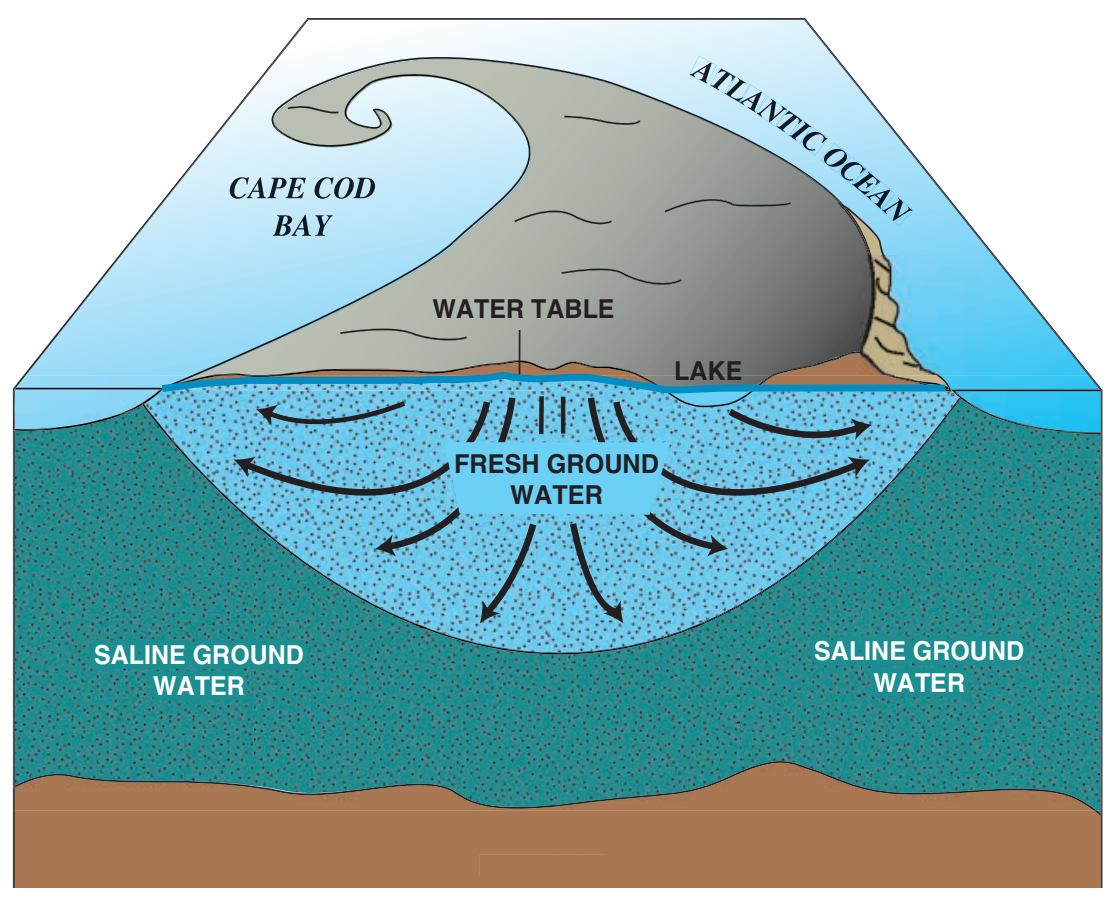

Figure 3. Freshwater underlain by saltwater forms the flow lenses of the Lower Cape Cod aquifer system (modified from Strahler, 1972).

The remnants of the once much larger deltaic deposits, or outwash plains, that now constitute Lower Cape Cod continue to be eroded at a retreat rate of about 3 feet $(\mathrm{ft})$ per year along the Atlantic Ocean (Zeigler and others, 1964). These surficial deposits overlie granitic bedrock and range in thickness from about $500 \mathrm{ft}$ in Eastham to over 1,000 ft in Truro (Oldale, 1992).

\section{Kettle-Hole Ponds}

Kettle-hole ponds are the most conspicuous freshwater feature found throughout Lower Cape Cod (fig. 4). These ponds are surface-water expressions of the water table because they directly connect with the underlying aquifer system. Kettle-hole ponds are also flow-through ponds with freshwater seeping into and exiting the pond in the direction of ground-water flow. The kettle holes were formed by blocks of ice stranded by the retreating ice sheets and buried by the deltas that expanded into Glacial Lake Cape Cod. These ice blocks were stranded directly atop basal till and bedrock. When the buried ice blocks melted, overlying and surrounding sands and gravels collapsed into the resulting depressions. These depressions eventually became ponds when they filled with ground water as the water table rose in response to the rising seas. These kettle-hole ponds are found throughout north Wellfleet and south Truro within the CCNS (fig. 1).

\section{Pamets}

Valleys, known as pamets, carved the originally flat, outwash-plain surfaces throughout Lower Cape Cod. These pamets formed possibly by "spring sapping," a process in which springs migrated inland from the coast by gradually eroding the gently sloping land surface to form a series of east-west trending stream valleys (Oldale, 1992). These pamets sometimes are referred to locally as "hollows," and can be found throughout the Wellfleet and Truro areas. The most notable pamet on Lower Cape Cod is the valley that contains the Pamet River in Truro (fig. 1).

\section{Aquifer System}

The freshwater-flow lenses of the Lower Cape Cod aquifer system consist of four water-table mounds separated by surface-water discharge areas. For example, the Pamet River is the hydrologic boundary between the Pamet and Chequesset ground-water-flow lenses (fig. 1). Each flow lens is sustained (recharged) by precipitation that percolates through the ground to the water table, the top of the aquifer. Generally, ground water flows radially at a rate of about 1-2 ft per day from the highest point of the water table toward the coast and toward the streams and wetlands that form the boundaries between the lenses. Recharge near the center of the water-table 




mound travels deeper through the aquifer system than water that recharges near the coast (fig. 3). The water that travels along the deeper flow paths to the coast (fig. 3) can take more than 100 years to reach the coast.

All of the freshwater that flows through the Lower Cape Cod aquifer system is derived from aquifer recharge. Under current (2005) conditions, flow from one flow lens does not discharge to another flow lens; therefore, the four flow lenses are hydraulically independent of one another (Masterson, 2004) (fig. 1).

\section{Water Table}

The elevation of the water table is typically referred to in terms of altitude above the mean sea-level elevation of 1929 (NGVD 29). The altitudes of the tops of the water-table mounds (fig. 1) range from about 16 $\mathrm{ft}$ above NGVD 29 in the Nauset flow lens to about 6 $\mathrm{ft}$ above NGVD 29 in the Pilgrim flow lens. Surfacewater bodies, local geology, and changing ground-water pumping and recharge conditions affect the altitude and shape of the water-table mounds. The Chequesset flow lens, which receives the most recharge of the four flow lenses, has a maximum altitude of only about $9 \mathrm{ft}$ above NGVD 29, which is about $7 \mathrm{ft}$ lower than the altitude of the Nauset flow lens; this difference is caused by the large number of streams, such as the Herring River in Wellfleet, that flow in the Chequesset flow lens and by the differences in the permeability of the glacial sediments of the Nauset and Chequesset flow lenses (Masterson, 2004).

The altitudes of the water-table mounds vary seasonally and annually because aquifer recharge rates vary with changes in precipitation and temperature. These rates also may vary from one flow lens to another because of differences in land use, vegetation, depth to the water table, and local rainfall. Water levels at observation well TSW-89 in north Truro (fig. 1) correlated strongly with rainfall (fig. 5) measured at the nearby National Atmospheric Deposition Program site in south Truro (NADP Site, fig. 1). Changes in precipitation, and therefore, aquifer recharge, also result in changes in 


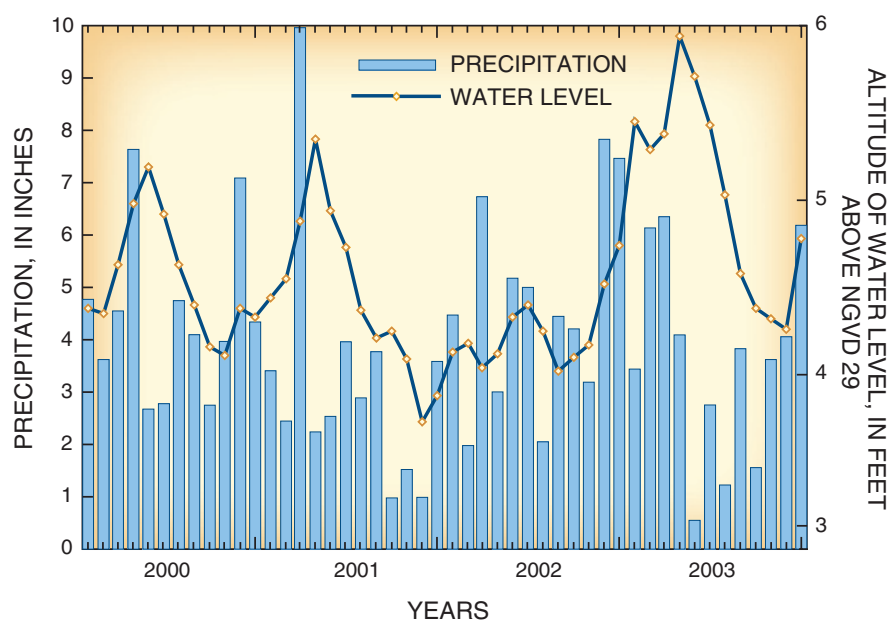

Figure 5. Changes in water levels are directly correlated to changes in precipitation as shown by the change in rainfall at the National Atmospheric Deposition Program site in Truro and water levels at observation well TSW-89 in North Truro, Cape Cod, Massachusetts, from 2000 to 2003.

pond levels, streamflow, and discharge to the coast. The magnitudes of these changes vary across a flow lens and from flow lens to flow lens.

Water-level fluctuation, in response to changes in recharge, is greatest at the top of a water-table mound away from streams and the coast because water levels change less in areas where ground water discharges (Masterson, 2004). Duck Pond, which is near the top of the southern water-table mound in the Chequesset flow lens (fig. 1), had a mean annual fluctuation of about $1.6 \mathrm{ft}$, as determined from monthly measurements from 1994 to 1999 (Sobczak and others, 2003). In contrast, Gull Pond, which is close to the Herring River and is connected to nearby kettle ponds by a network of shallow, dug channels, had a mean annual fluctuation of about $0.7 \mathrm{ft}$ during that same period.

\section{Water Budget}

Precipitation is the primary source of freshwater to the Lower Cape Cod aquifer system. On average, the rainfall rate is about 42 inches per year (in/yr). It is assumed that about 43 percent of the water ( $18 \mathrm{in} / \mathrm{yr})$ is removed by evaporation and plant transpiration before reaching the water table; the remaining water (24 in/yr) enters the aquifer as recharge. If a recharge rate of 24 $\mathrm{in} / \mathrm{yr}$ is assumed over the entire Lower Cape Cod land mass, then freshwater continually flows through and leaves the aquifer at a rate of about 2.5 billion gallons per year, or about 68 million gallons per day (Mgal/d) (fig. 6). Ground-water-flow simulations were made to determine how much of this freshwater discharges directly to the coast through the seabed or reaches the coast as streamflow (Masterson, 2004).

The total water budget for the Lower Cape Cod aquifer system can be subdivided by individual flow lenses (fig. 6). Subdividing the water budget by flow lens provides a better understanding of the distribution of flow to the various hydrologic features than can be obtained from the total water budget for the entire aquifer system. For instance, the total amount of ground-water discharge to streams is about $21 \mathrm{Mgal} / \mathrm{d}$, or 31 percent of the total water budget for the Lower Cape Cod aquifer system, but nearly 60 percent of that streamflow is in the Herring River in Wellfleet, which bisects the Chequesset flow lens (fig. 1).

Ground-water withdrawals for public supply account for only about 1 percent of the total water budget for the aquifer system; however, almost all of the pumped water is from the Pamet flow lens, composing about 7 percent of its total budget (fig. 6). This pumped water is the primary source of drinking water for the town of Provincetown, parts of the town of Truro, and some NPS facilities in the Provincetown area. Most of the wastewater derived from this public supply is discharged into the Pilgrim flow lens as treated sewage at the Provincetown wastewater-treatment facility

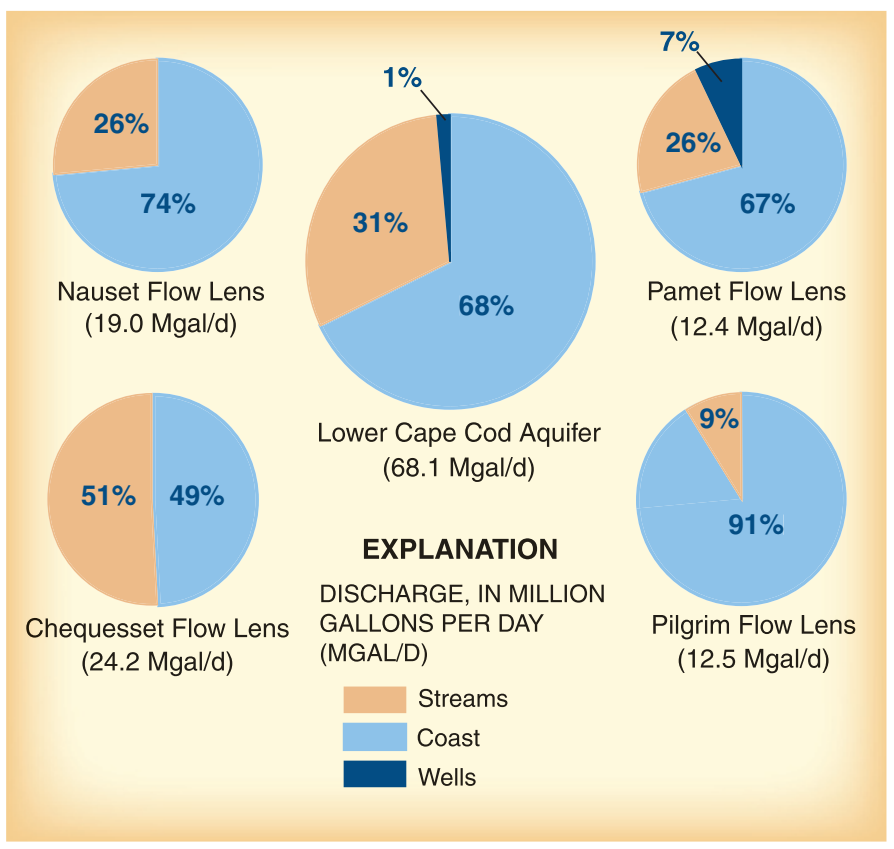

Figure 6. The hydrologic budget of the Lower Cape Cod aquifer system can be subdivided by individual flow lenses to show the relative importance of the different flow components in each flow lens. 
infiltration beds (fig. 1), with the remainder being discharged through onsite domestic septic systems in unsewered areas.

\section{Freshwater/Saltwater Interface}

The Lower Cape Cod land mass is small, thereby limiting freshwater recharge, aquifer area, and aquifer depth. Consequently, freshwater in the Lower Cape Cod aquifer system does not extend to the underlying granitic bedrock, but instead is primarily bounded below by saltwater (fig. 3). Depths to the boundary, or interface, between fresh and saltwater within the aquifer system differ among the flow lenses, and are directly proportional to the altitude of the overlying water table. Because of the density difference between fresh and saltwater, the depth to the freshwater/ saltwater interface below sea level is about 40 times greater than the altitude of the water table above sea level (Freeze and Cherry, 1979). Therefore, if the water table is $5 \mathrm{ft}$ above sea level, the depth to the freshwater/saltwater interface would be about 200 $\mathrm{ft}$ below sea level. Although this is only a general approximation of the actual relation between fresh and saltwater flow, it does provide reasonable estimates of the depths to the freshwater/saltwater interfaces throughout the Lower Cape Cod aquifer system.

\section{Ground-Water Flow and its Effect on Ecology}

In addition to being the only source of drinking water for the communities of Lower Cape Cod, ground water is also the primary source of freshwater for kettle-hole ponds, inland wetlands, vernal pools, streams, and coastal waters. These water bodies support much of the biodiversity found throughout the CCNS. The amount of and changes in ground-water discharge over time are essential in maintaining the freshwater and estuarine habitats throughout the CCNS.

\section{Kettle-Hole Ponds}

Because of the connection between kettle-hole ponds and the aquifer system, ground water discharges from the aquifer into the ponds primarily close to the shore, through the often highly vegetated zone along the shoreline. The shoreline plant and animal communities, often including rare species, are especially adapted to tolerate seasonal flooding, and depend on naturally high water levels to prevent displacement by less flood-tolerant species (Sorrie, 1994).
The continual refreshing of pond water with ground water reduces the effects of natural salts, such as sea spray, and pollutants, such as from domestic wastewater systems adjacent to the ponds. This flushing process maintains the naturally dilute, clear, and slightly acidic water quality found in the kettle-hole ponds throughout the CCNS.

\section{Inland Wetlands}

Inland wetlands, such as shrub and tree swamps and vernal pools, are similar to kettle-hole ponds in that they form in low-lying areas and rely on groundwater discharge as their primary source of freshwater. Seasonally flooded wetlands, such as vernal pools, typically contain water in winter and early spring, when the water table is high and low-lying areas are temporarily flooded; they regularly are dry in midsummer (fig. 7). This regime of periodic flooding and drying creates habitat for a diverse and distinct group of plants, and particularly, vernal-pool animals, including mole salamanders, wood frogs, and many invertebrates, which could not survive or reproduce successfully in the presence of permanent-pond predators, especially fish (Colburn, 2004).

Natural ground-water levels also sustain red maple and Atlantic white cedar swamps, which have their own distinct biotic communities (fig. 8). These wetlands provide important sources of water to wildlife species, such as box turtles, that otherwise inhabit dry upland landscapes during the summer.

\section{Streams}

On Lower Cape Cod, freshwater streams are at the head of small estuaries, with the largest streams being the Herring River in Wellfleet and the Pamet River in Truro (fig. 1). These streams supply freshwater to coastal waters and provide the necessary pathway between the coast and the kettle-hole ponds for migratory fish like the anadromous blue-back herring and alewife, which spawn in the kettle-hole ponds; and for catadromous American eels, which mature in the upper estuary and kettle ponds but spawn in the ocean. Ground-water discharge through the streambed is the primary source of freshwater for these streams. Similar to ponds and wetlands, streams flow in low-lying areas where land surface intersects the water table. Therefore, the amount of flow in these streams is directly related to the altitude of the water table, and small changes in the altitude of the water table can cause large changes in streamflow, which could impede fish migration. 
A.

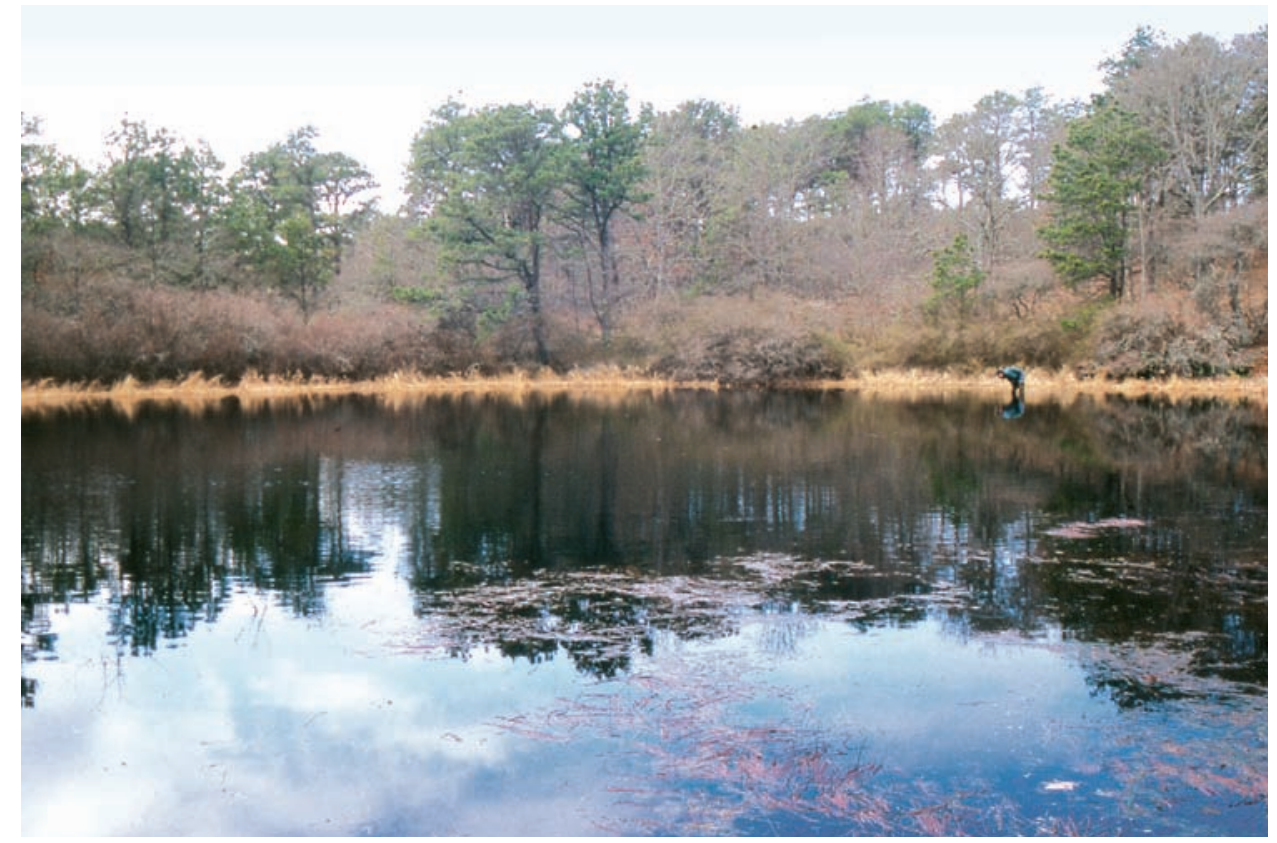

B.

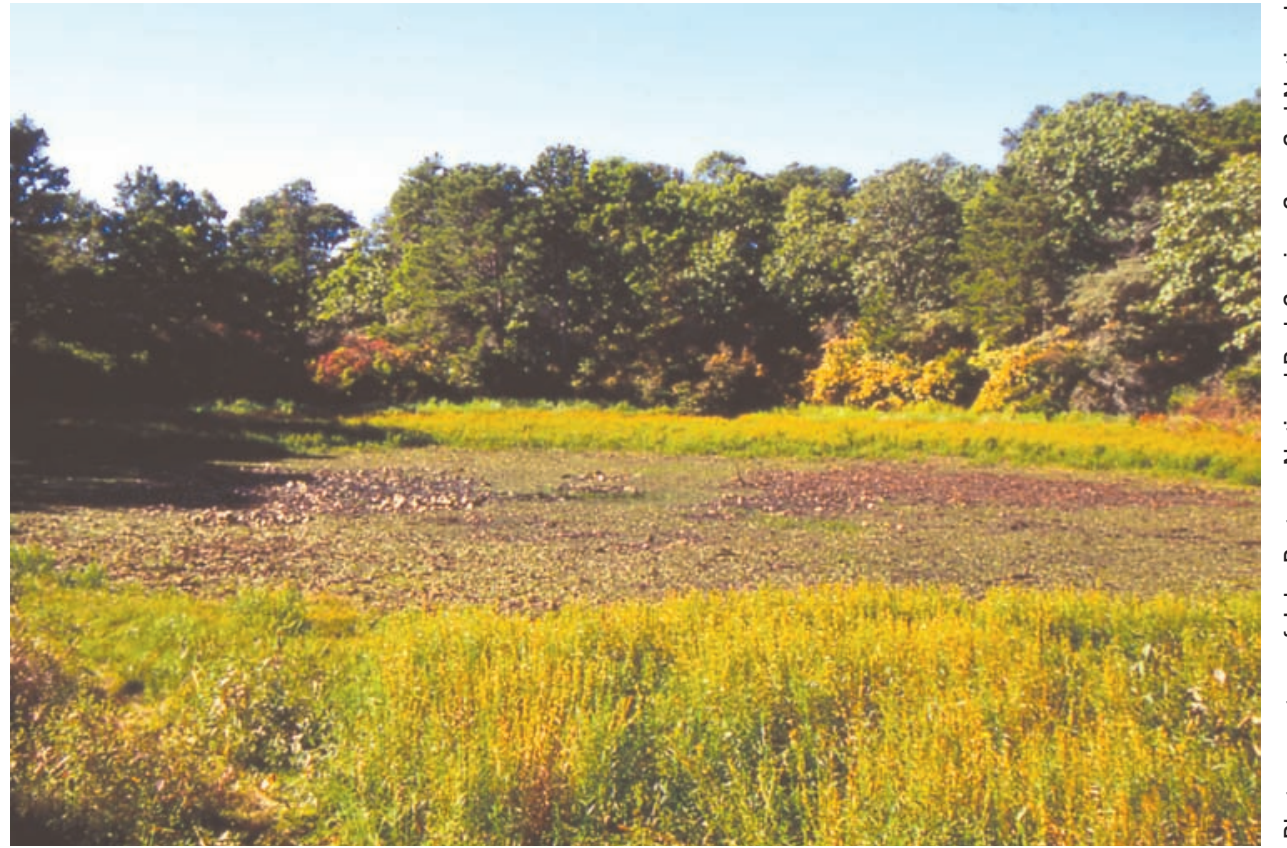

Figure 7. Vernal pools on Lower Cape Cod are seasonally flooded wetlands that typically contain water in the winter and early spring when the water table is $(A)$ high and are regularly dry in the summer and early fall when the water table is $(B)$ low. This regime of periodic flooding and drying is vital for the life cycles of the diverse plant and animal life that inhabit these areas. 


\section{A.}

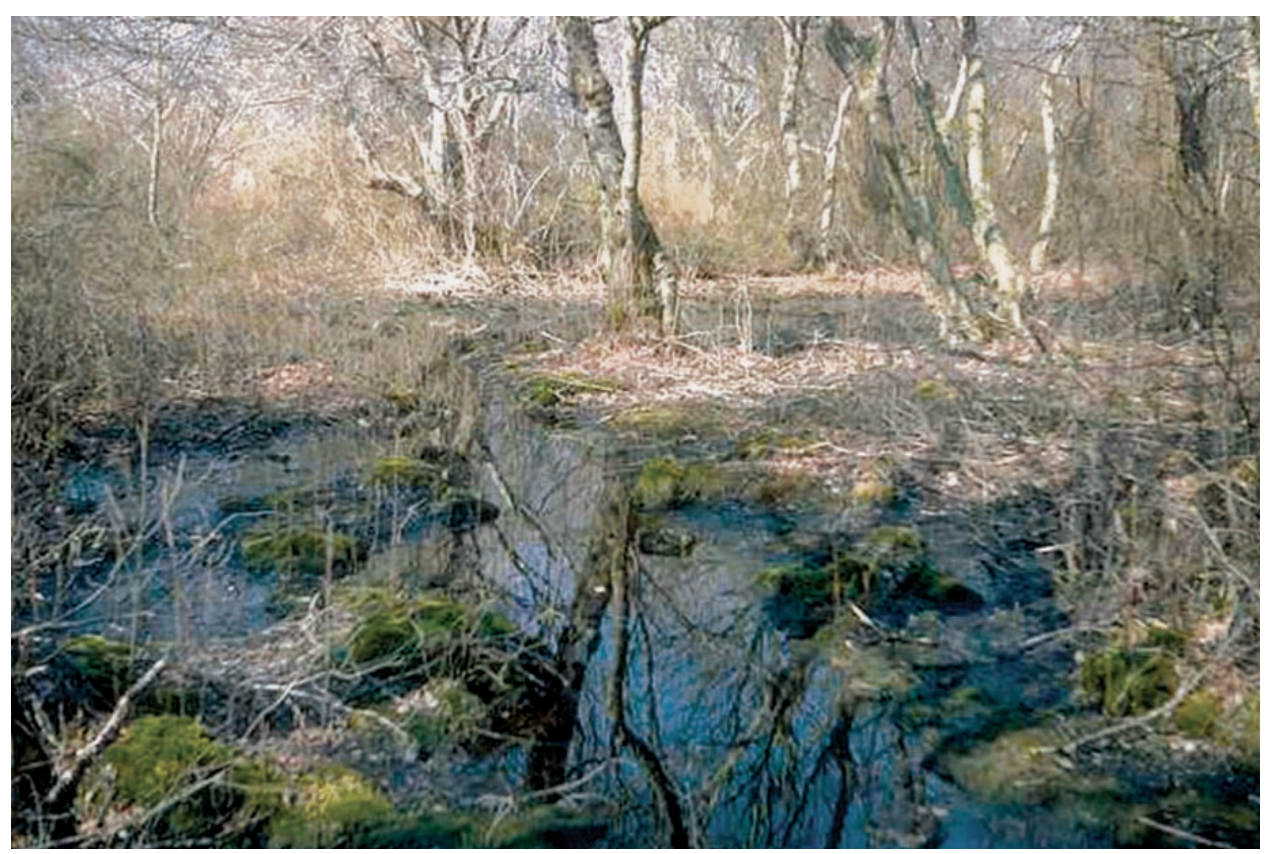

B.

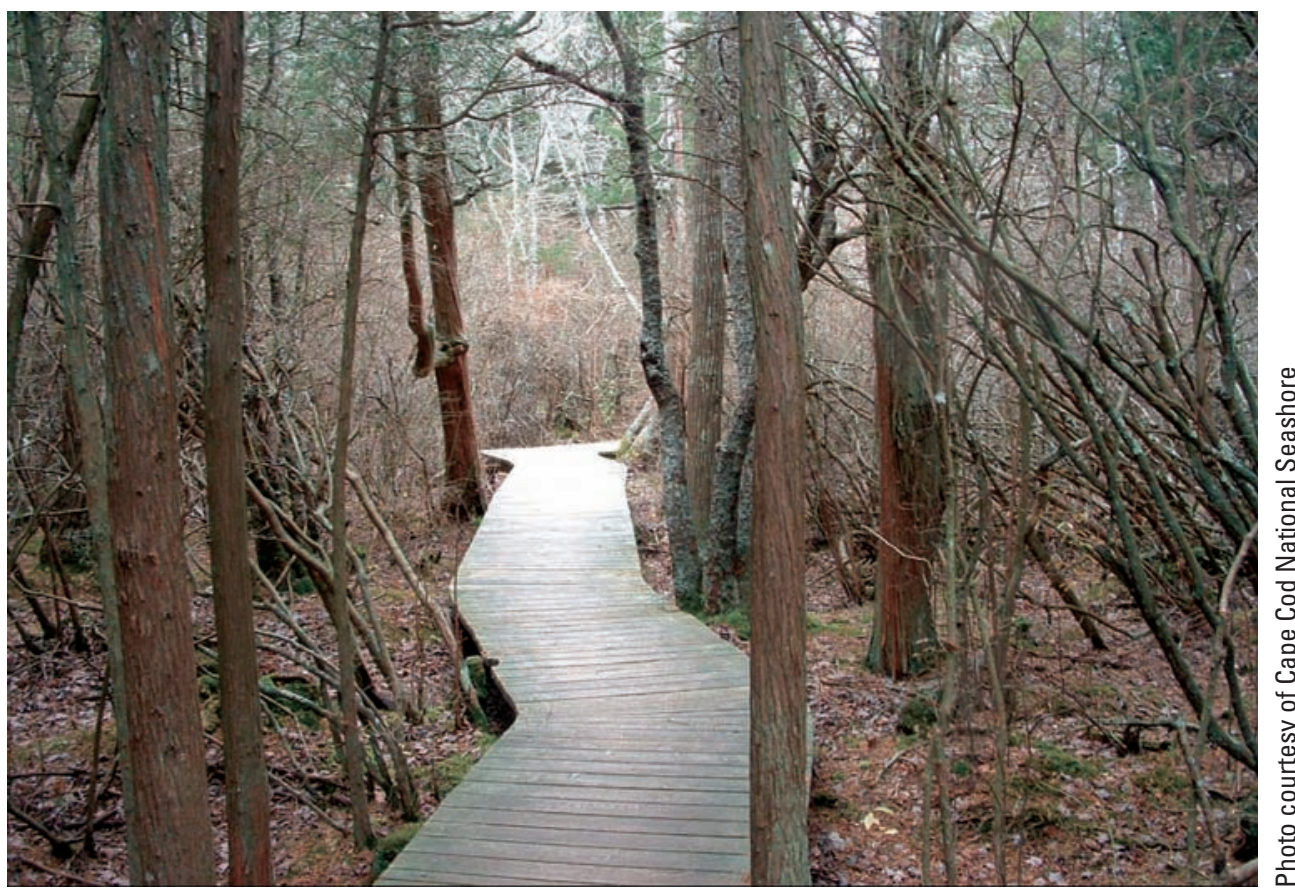

Figure 8. The inland red maple $(A)$ and white cedar $(B)$ swamps throughout Lower Cape Cod depend upon the natural fluctuations in ground-water levels to support their distinct biotic communities. 


\section{Coastal Waters}

The coastal waters, including coastal marshes, that surround Lower Cape Cod are the ultimate discharge areas for freshwater from the ground-water-flow system (Walter and others, 2004). Freshwater enters the coastal waters as either streamflow or as direct ground-water discharge from the aquifer through the coastal seabed. About two-thirds of the $68 \mathrm{Mgal} / \mathrm{d}$ of freshwater discharging to the coast is direct ground-water discharge, and the remainder enters coastal waters as surface water from streams (fig. 6). Freshwater discharge to the coast is essential for maintaining the natural range of salinity in coastal waters and salt marshes, which sustains a diversity of shellfish and finfish habitats in the nearshore areas that surround Cape Cod.

\section{Changes in Ground-Water Flow and their Effects on Water Resources}

Changes on Lower Cape Cod that may affect groundwater quality and flow in the aquifer system include (1) increased land development and population growth, which could affect the quality and quantity of ground water for both drinking water and for the maintenance of freshwater and coastal ecosystems, (2) estuarine habitat restoration through the removal of tide-control structures and possible alterations to ground-water quality as a result of restoring natural tidal fluctuations, and (3) sealevel rise and its effect on water levels, streamflows, and the depth to the freshwater/saltwater interface.

\section{Land Development and Ground-Water Quality}

The primary concerns related to increased land development are the increase in nonpoint-source contamination to the aquifer from septic systems and lawn fertilizers, and point-source loading from gasoline stations and municipal landfills (Godfrey and others, 1999). Increased loading of nutrients, such as nitrogen and phosphorus, to the aquifer is of particular concern because of the potential for increased eutrophication of fresh and coastal surface-water bodies. Eutrophication is the process by which continued nutrient loading to surface-waters bodies stimulates excessive plant and algae growth; the resulting accumulation of organic matter can lead to the depletion of dissolved oxygen and to fish kills. In coastal waters, nutrient enrichment has caused nuisance algal blooms (fig. 9) and the loss of eelgrass beds, an important submerged aquatic habitat for shellfish and finfish (Short and Burdick, 1996).

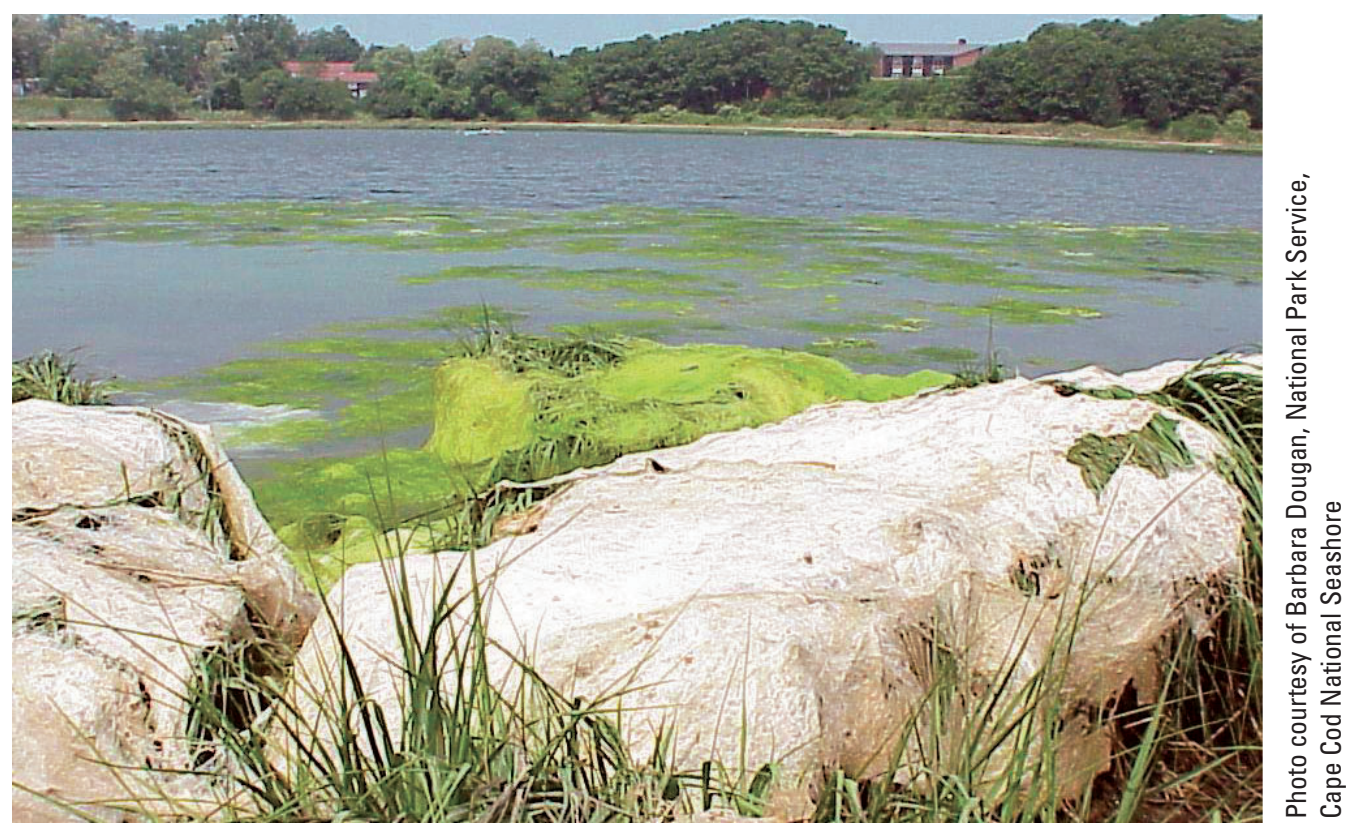

Figure 9. Increased discharge of nutrients to surface-water bodies has caused eutrophication and resulted in nuisance algal blooms, such as the one shown here at Salt Pond, Eastham, Massachusetts. These human-derived nutrients are transported through the ground-water system from onsite septic systems to surface-water bodies. 
Depending on the source of recharged water, many toxic constituents may flow with ground water and affect aquatic ecosystems. On Lower Cape Cod, domestic wastewater, which includes many compounds intended for household or medicinal use, is generally disposed of through onsite septic systems. These contaminants may affect both ground-water supplies and downgradient surface-water ecosystems (John Colman, U.S. Geological Survey, written commun., 2003), with potential chronic or acute effects to both individual species and entire ecosystems.

\section{Land Development and Ground-Water Flow}

Presently (2004), only Provincetown and portions of Truro are serviced by a large capacity, municipal watersupply system that withdraws water from the Pamet flow lens. Other portions of Lower Cape Cod obtain drinking water from shallow, private wells. As land development increases and wastewater continues to be returned to the aquifer through onsite septic systems, there is a growing concern that increased amounts of nonpoint-source contamination in the aquifer system may degrade the water supply. If the water supply is adversely affected, it may necessitate a shift from small-capacity, private wells to larger, more centralized municipal systems that can be managed more efficiently than the current water supply (Sobczak and Cambareri, 2002). Federal, State, and local officials responsible for managing and protecting water resources are concerned that such a shift may cause ecologically detrimental declines in the water table and in pond levels, and cause decreased ground-water discharge to streams and coastal areas, and increased risk of saltwater intrusion.

A pumping well can alter ground-water discharge to downgradient surface-water bodies by capturing water that would discharge to these bodies (figs. 10A, B); and if the pumping rate is great enough, by reversing the flow direction so that the surface-water bodies contribute water directly to the pumping well (fig. 10C). This pumping can cause declines in pond levels, increases in the depth to the water table beneath inland wetlands, reductions in streamflow, and reductions in ground-water discharge to the coast. These changes can reduce the water available to shoreline plants, decrease the flooding depth and duration of vernal pools, impede migratory fish passage, and alter the salinity of estuaries, all of which alter a diverse biotic community.

Saltwater intrusion is another potentially adverse effect of centralized large-capacity municipal pumping on the ground-water-flow system. Saltwater intrudes into freshwater when a pumped well removes enough


Figure 10. Pumping from ground water can affect discharge to nearby surface-water bodies. In the prepumping condition $(A)$, water flows to the surface-water body. Pumping at a low rate $(B)$ reduces discharge to the surface-water body. When the pumping rate is increased $(C)$ the flow direction reverses and water from the surface-water body is pumped directly from the well (modified from Alley and others, 1999).

fresh ground water to cause the interface between fresh and saltwater to move in from the coast or up from the underlying saline part of the aquifer (fig. 11).

\section{Salt-Marsh Diking and Tidal Restoration}

Ongoing efforts to restore tidal flow to Lower Cape Cod coastal marshes, restricted for the past 150 years for mosquito control, marsh drainage, and flood control, may affect the ground-water-flow system. Tide-control structures (fig. 12) were built at the Herring River in Wellfleet, the Pamet River and East Harbor (Pilgrim Lake) in Truro, and Hatches Harbor in Provincetown. These structures restrict tidal flow, reduce high-tide heights, impede low-tide drainage, and thereby degrade 


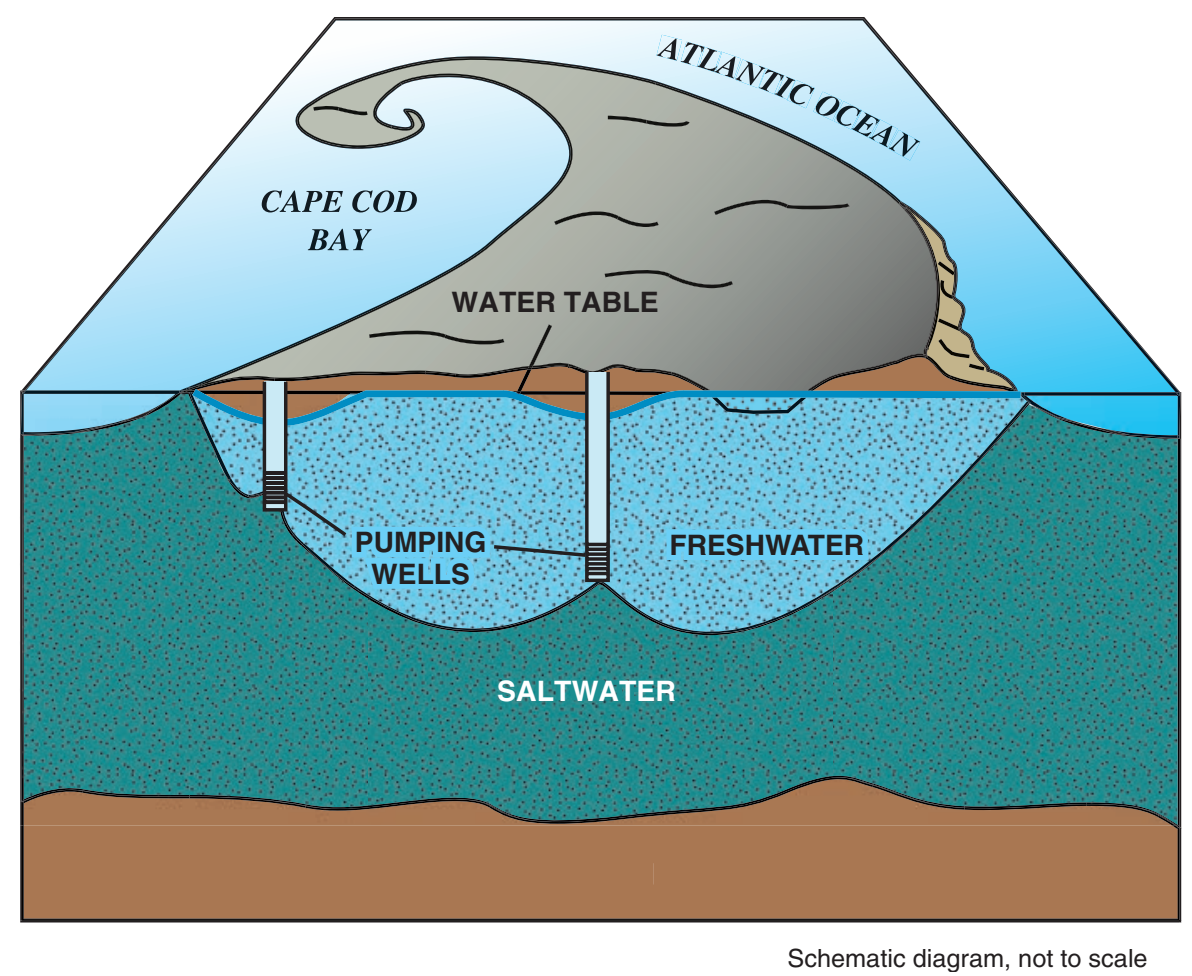

Figure 11. Overpumping from large-capacity municipal wells, such as those in the Pamet flow lens, can result in lateral encroachment and upconing of saltwater (modified from Strahler, 1972).

nearly 2,500 acres of original salt-marsh estuaries on Lower Cape Cod (fig. 1) (Roman and others, 1995). As a result, NPS and other Federal, State, and local resource managers are assessing the potential hydrologic and ecological effects of removing tide-control structures and monitoring the results of ongoing restoration at Hatches and East Harbors to determine whether these marshes are returning to their natural state.

\section{Effects on Estuarine Habitats}

With the installation of large culverts in the Hatches Harbor tide-control structure (Provincetown, MA) in 1998, tidal range has been mostly restored after 68 years of diking. Seawater is again flooding the wetlands during high tides, causing the decline of exotic and invasive plants, especially common reed (Phragmites), and the recolonization of the marsh by native salt-marsh plants and animals. In addition, better low-tide drainage and tidal flushing have naturally controlled mosquitoes (Portnoy and others, 2003).

With partial tidal restoration at East Harbor (Pilgrim Lake, fig. 1) in 2002, nuisance midges and introduced carp have been replaced by a rich assemblage of native estuarine finfish, shellfish, and submerged aquatic vegetation, such as widgeon grass and eelgrass.
This system, diked since 1868 , had chronic eutrophication, summertime oxygen depletions, and nuisance insect problems for decades prior to the 2002 partial opening.

The largest diked estuary on the Lower Cape is the Herring River (Wellfleet, MA). Restoration of this estuary, tide-restricted since 1909 , is expected to eliminate water-quality problems, and also to restore up to 1,100 acres of native salt-marsh estuary (Roman and others, 1995).

Presently, much of this marsh is constantly drained, leading to the leaching of acid sulfates and metals, which in turn stresses fish and other aquatic animals, and favors nuisance mosquitoes. Drainage has also allowed trees and shrubs to replace original salt-marsh plants, and has caused the original water-logged peat to shrink and subside. Wetland subsidence combined with sea-level rise may prohibit long-term wetland survival. Hydrologic and ecological research has shown that restored tidal flow can reverse these trends and restore native habitats (Portnoy, 1999; Spaulding and Grilli, 2001; Portnoy and others, 2003). Finally, tidal restoration of the upper Pamet River (fig. 1) marshes, diked since about 1869, has been considered, particularly after a 1991 breach of the barrier beach separating the Pamet River from the Atlantic Ocean (Portnoy, 2001). 


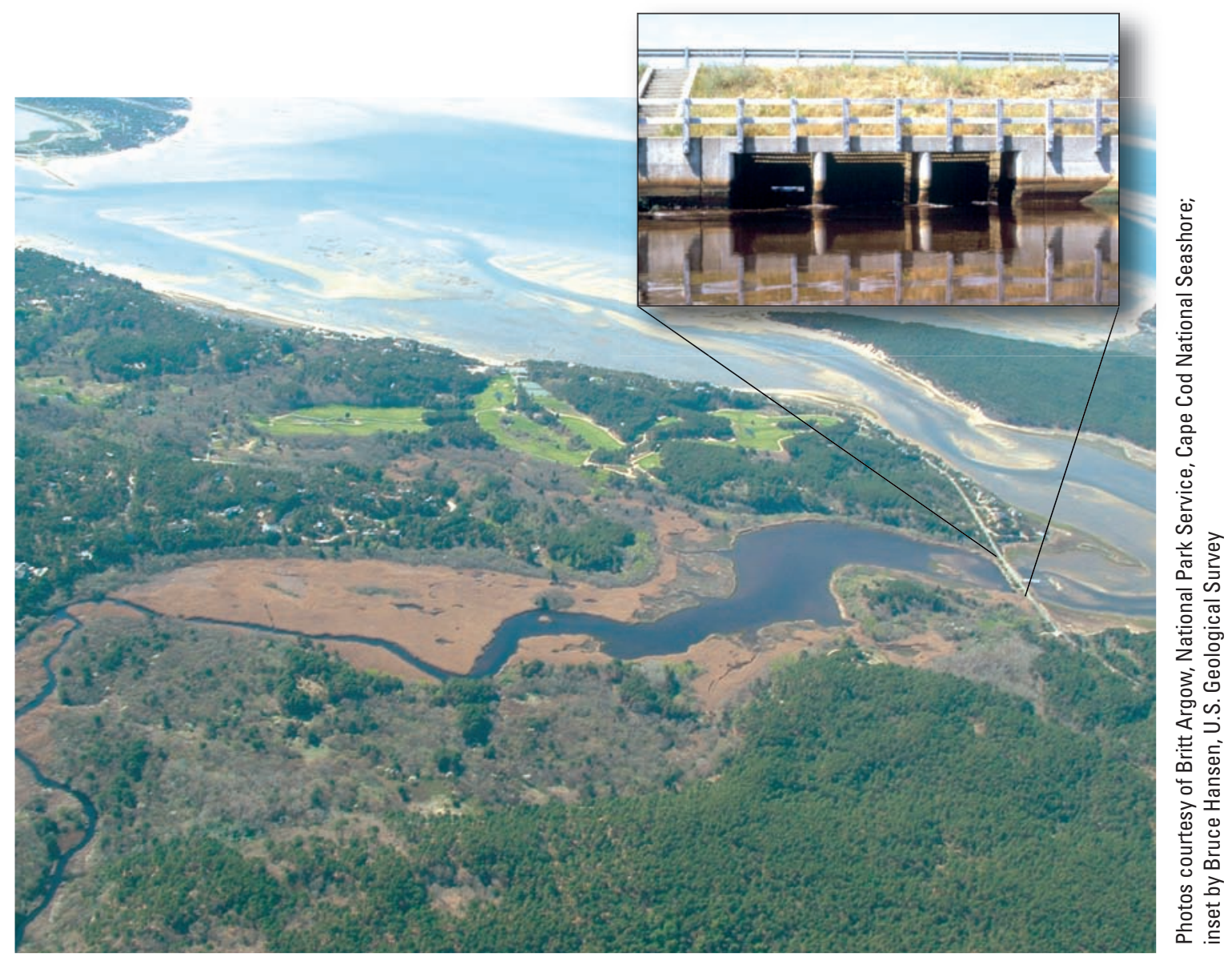

Figure 12. Tide-control structures open at low tide to allow freshwater to flow to the coast and close at high tide to prevent saltwater from flooding original salt marshes, such as in the Herring River Basin. The ecologically damaging effects of tide restrictions are prompting tide-restoration projects on Cape Cod and throughout the world.

\section{Effects on Ground-Water Resources}

Proposed tide restorations to the upper Pamet River and Herring River (fig. 1) have raised concerns about the potential effects on nearby residents from projected increases in tidal exchange. Specifically, restored tidal flow could increase ground-water levels, compromising onsite septic systems, or disturb the freshwater/saltwater interface, affecting domestic wells in the adjacent developed uplands. The Cape Cod Commission, however, determined that removal of the tide-control structure on the Pamet River would not substantially affect the surrounding areas (Eichner and others, 1997); the NPS and USGS have determined a similar result for the Herring River (Martin, 2004; Masterson, 2004).

In the case of the Herring River, results of hydrodynamic and salinity modeling (Spaulding and Grilli, 2001) indicate that the most likely scenario for the removal of the tide-control structure at the mouth of the Herring River in Wellfleet (fig. 12) will result in increased tidal exchange in the river and a landward flooding of seawater less than $2 \mathrm{ft}$ above the current mean tide. Ground-water-flow modeling results (Masterson, 2004), which include the predicted increase in stream stage and landward encroachment of saline surface waters, indicate no appreciable effect on the depth to the freshwater/saltwater interface in the areas adjacent to the river.

\section{Sea-Level Rise}

Residents of coastal areas are increasingly concerned about the effects of sea-level rise. The National Oceanic and Atmospheric Administration (2003) reports a rising trend in sea level at the Boston Harbor Tide Gage, which has been operated since 1921, of about $0.104 \mathrm{in} / \mathrm{yr}$ or about $0.87 \mathrm{ft}$ per 100 years. The Intergovernmental Panel on Climate Change (IPCC) predicts that global seas may rise by an additional 0.5 to $3.1 \mathrm{ft}$ by the year 2100 , with a best estimate of $1.6 \mathrm{ft}$ (Intergovernmental 
Panel on Climate Change, 2001). This rate of rise would be nearly double the rate of rise observed at Boston Harbor over the past 80 years. Areas most susceptible to rising sea levels are coastal aquifers, such as Cape Cod, which raises concerns of potential effects of sea-level rise on coastal habitats and drinking-water supplies (Intergovernmental Panel on Climate Change, 2001; Moore and others, 1997).

\section{Sea-Level Rise and Coastal Habitats}

The primary concerns about the effects of sea-level rise on coastal habitats include increased erosion rates, damage from higher storm-surge flooding (Gornitz, 1991; Theiler and Hammar-Klose, 2000), and landward intrusion of seawater in coastal wetlands (Donnelly and Bertness, 2001). Damage from increased storm-surge flooding is a concern on Lower Cape Cod because of the potentially severe effects these storms can have on the coastal areas along the CCNS. During the "Perfect Storm" of October 31, 1991, the storm surge breached the barrier dune separating the Pamet River from the Atlantic Ocean and forced seawater up to several feet deep onto the low-lying flood plain (fig. 13). Tidal restrictions near the mouth of the Pamet River (fig. 1) since 1869 have converted the upper Pamet River plant community from salt marsh to salt-intolerant wetland species. After the breach in 1991, seawater persisted for over a week in the river proper, and for months in the sediment. Extensive mortality of current freshwaterwetland vegetation was averted only because plants were dormant at that time (Portnoy, 2001).

\section{Sea-Level Rise and Drinking-Water Supplies}

A concern for Lower Cape Cod water managers is the potential adverse effect of sea-level rise on the depth to the freshwater/saltwater interface near public-supply wells (fig. 11). Pumping from public-supply wells in coastal aquifers underlain by saltwater can lower the water table relative to sea level, decrease the depth to the freshwater/saltwater interface beneath the pumping well, increase the potential for saltwater intrusion, and thereby limit the yield of potable water from the well. Successive increases in the pumping rate can decrease the depth of the freshwater/saltwater interface until a critical distance between the well screen and the top of the interface is achieved, at which point saltwater may be drawn into the well (fig. 11) (Reilly and Goodman, 1985; Reilly and others, 1987).

In the mid-1950s, overpumping of wells in the Knowles Crossing well field in North Truro (fig. 1) caused saltwater intrusion, creating the need
A.

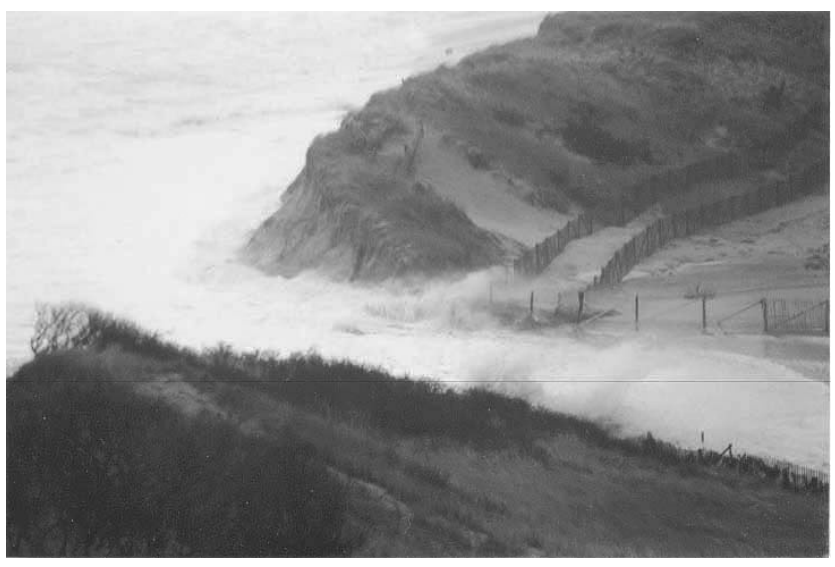

B.

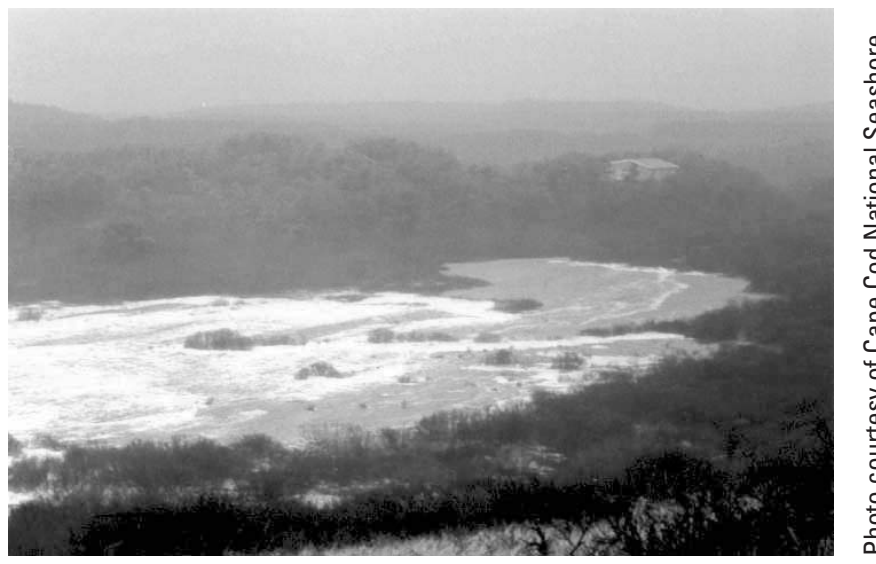

Figure 13. Overwash at Ballston Beach, Truro during the "Perfect Storm" of October 31, 1991. The storm surge breached the barrier dune $(A)$ and forced seawater onto the flood plain to a depth of several feet $(B)$.

for additional water-supply wells (Masterson, 2004). In 1955, the Provincetown Water Department began pumping from the South Hollow well field in the center of the Pamet flow lens to meet the increased water demand (fig. 1).

Sea-level rise may exacerbate the effects of increased pumping, as was done in the 1950s, and increase the potential for saltwater intrusion into a pumping well. As sea level rises over time, the water table will rise along with it so that the height of the water table relative to sea level will not change. Under these conditions, the depth to the freshwater/saltwater interface below the water table also will not change. However, if the aquifer system were additionally stressed by a high pumping rate, the water table near the well may remain constant or decline even as sea level rises. In this case, the height of the water table above sea level would decrease, as would 
the depth to the freshwater/saltwater interface. This relation indicates that sea-level rise in coastal aquifers, such as Lower Cape Cod, may result in a decrease in the potential yields of a pumping well that is subject to saltwater intrusion, and may necessitate limiting pumping rates at well fields to prevent saltwater contamination of public-water-supply systems.

\section{Summary}

Ground water is a vital resource on Lower Cape Cod because it is the only source of drinking water and the primary source of freshwater that discharges into kettle-hole ponds, streams, and estuaries. It is also a key component in the maintenance of ecologically diverse habitats throughout the Cape Cod National Seashore. Because of the importance of this resource, the U.S. Geological Survey, in cooperation with the National Park Service, Massachusetts Executive Office of Environmental Affairs, Cape Cod Commission, and the Towns of Eastham, Provincetown, Truro, and Wellfleet, began an investigation in 2000 to improve the understanding of the hydrogeology of the Lower Cape Cod aquifer system and to assess possible hydrologic effects of proposed water-management strategies.

This report briefly details the hydrogeology of the Lower Cape Cod aquifer system and discusses the importance of ground-water levels and flow to the functioning of freshwater and estuarine ecosystems of the Cape Cod National Seashore. It includes a discussion of the implications of future changes to the ground-water system and their potential effects on ecosystems and water resources of Lower Cape Cod.

Changes on Lower Cape Cod, including land development, population growth, and sea-level rise, have created concerns for potentially adverse effects on the ecology and ground-water flow of the Cape Cod National Seashore. The potential effects of increased loading of nutrients, such as nitrogen and phosphorus, include the eutrophication of fresh and coastal surfacewater bodies. The potential effects of increased ground-water withdrawals include declines in pond levels, increases in the depth to the water table beneath inland wetlands, reductions in streamflow, reductions in ground-water discharge to the coast, and increased saltwater intrusion. Finally, the potential effects of rising sea levels include increased erosion rates, damage from higher storm-surge flooding, landward intrusion of seawater in coastal marshes and wetlands, and a decrease in the thickness of the freshwater lens.

\section{Acknowledgments}

The authors thank Kathryn Hess of the U.S. Environmental Protection Agency, and Larry Martin and Charlie Roman of the National Park Service for their helpful reviews of this publication.

\section{References Cited}

Alley, W.M., Reilly, T.E., and Franke, O.L., 1999, Sustainability of ground-water resources: U.S. Geological Survey Circular 1186, 79 p.

Colburn, E.A., 2004, Vernal Pools-History and Conservation: Blacksburg, Virginia, McDonald \& Woodward Publishing Co., 426 p.

Donnelly, J.P., and Bertness, M.D., 2001, Rapid shoreward encroachment of salt marsh cordgrass in response to accelerated sea-level rise, in Proceedings of the National Academy of Sciences, v. 98, no. 25, p.14218-14223.

Eichner, Eduard, Cambareri, T.C., Livingston, Kenneth, Sobczak, R.V., and Smith, B.S., 1997, Pamet River investigation groundwater assessment study: Cape Cod Commission, $39 \mathrm{p}$.

Freeze, J.G., and Cherry, J.A., 1979, Ground Water: Englewood Cliffs, New Jersey, Prentice-Hall, Inc., 604 p.

Godfrey, P.J., Galluzzo, K., Price, N., and Portnoy, J.W., 1999, Water resources management plan-Cape Cod National Seashore, Massachusetts, National Park Service, 252 p.

Gornitz, V., 1991, Global coastal hazards from future sea-level rise: Palaeogeography, Palaeoclimatology, Palaeoecology (Global and Planetary Change Section), v. 89, p. 379-398,

Intergovernmental Panel on Climate Change, 2001, The regional impacts on climate change: An assessment of vulnerability, accessed April 30, 2003, at http://www.grida. no/climate/ipcc

Martin, Larry, 2004, Salt marsh restoration at Herring River-An assessment of potential salt water intrusion in areas adjacent to Herring River and Mill Creek, Cape Cod National Seashore: Technical Report NPS/NRWRD/NRTR2004/319, 44 p.

Masterson, J.P., 2004, Simulated interaction between freshwater and saltwater and effects of ground-water pumping and sea-level change, Lower Cape Cod aquifer system, Massachusetts: U.S. Geological Survey Scientific Investigations Report 2004-5014, 72 p. 
McCobb, T.M., and Weiskel, P.K., 2003, Long-term hydrologic monitoring protocol for coastal ecosystems: U.S. Geological Survey Open-File Report 02-497, 94 p.

Moore, M.V., Pace, M.L., Mather, J.R., Murdoch, P.S., Howarth, R.W., Folt, C.L., Chen, C.Y., Hemond, H.F., Flebbe, P.A., and Driscoll, C.T., 1997, Potential effects of climate change on freshwater ecosystems of the New England/Mid-Atlantic Region: Hydrologic Processes, v. 11, 925-947.

National Oceanic and Atmospheric Administration, 2003, Relative sea-level trends, accessed January 22, 2003, at http://www.coops.nos.noaa.gov/seatrnds.html

Nuttle, W.K., and Portnoy, J.W., 1992, Effect of rising sea level on runoff and groundwater discharge to coastal ecosystems: Estuarine, Coastal and Shelf Science, v. 34, p. 203-212.

Oldale, R.N., 1992, Cape Cod and the islands-The geologic story: East Orleans, Massachusetts, Parnassus Imprints, $205 \mathrm{p}$.

Portnoy, J.W., 1999, Salt marsh diking and restoration-Biogeochemical implications of altered wetland hydrology: Environmental Management, v. 24, p. 111-120.

Portnoy, J.P., 2001, Truro's upper Pamet River: Environmental history and future prospects-Environment Cape Cod, v. 4, p. 1-9.

Portnoy, J.W., Roman, C.T., Smith, Stephen, and Gwilliam, Evan, 2003, Estuarine habitat restoration at Cape Cod National Seashore-the Hatches Harbor prototype: Park Science, v. 22, p. 51-58.

Reilly, T.E., Frimpter, M.H., LeBlanc, D.R., and Goodman, A.S., 1987, Analysis of steadystate saltwater upconing with application at Truro wellfield, Cape Cod, Massachusetts: Ground Water, v. 25, no. 2, p. 82-92.

Reilly, T.E., and Goodman, A.S., 1985, Analysis of saltwater upconing beneath a pumping well: Journal of Hydrology, v. 89 , p. $169-202$.

Roman, C.T., Garvine, R.W., and Portnoy, J.W., 1995, Hydrologic modeling as a predictive basis for ecological restoration of salt marshes: Environmental Management, v. 19, p. 559-566.
Short, F.T., and Burdick, D.M., 1996, Quantifying eelgrass habitat loss in relation to housing development and nitrogen loading in Waquoit Bay, Massachusetts: Estuaries, v. 19, p. 730-739.

Sobczak, R.V., and Cambareri, T.C., 2002, Optimizing well placement in a coastal aquifer: Outer Cape Cod, Massachusetts: Journal of the American Water Resources Association, v. 38 , p. 747-757.

Sobczak, R.V., Cambareri, T.C., and Portnoy, J.W., 2003, Physical hydrology of selected vernal pools and kettle hole ponds in the Cape Cod National Seashore, Massachusetts: Cape Cod Commission, Barnstable, Massachusetts, 174 p.

Sorrie, B.A., 1994, Coastal plain ponds in New England: Biological Conservation, v. 68, p. 225-234.

Spaulding, M.L., and Grilli, A., 2001, Hydrodynamic and salinity modeling for estuarine habitat restoration at Herring River, Wellfleet, Massachusetts: Prepared for the National Park Service, U.S. Department of Interior, Cape Cod National Seashore, Wellfleet, Massachusetts, 93 p.

Strahler, A.N., 1972, The environmental impact of groundwater use on Cape Cod, Impact Study III: Orleans, Massachusetts, Association for the Preservation of Cape Cod, $68 \mathrm{p}$.

Theiler, E.R., and Hammar-Klose, E.S., 2000, National assessment of coastal vulnerability to sea-level rise-Preliminary results for the U.S. Atlantic coast: U.S. Geological Survey Open-File Report 99-593, 1 p.

Walter, D.A., Masterson, J.P., and Hess, K.M., 2004, Groundwater recharge areas and travel times to pumped wells, ponds, streams, and coastal water bodies, Cape Cod, Massachusetts: U.S. Geological Survey Scientific Investigations Map I-2857, 1 sheet.

Zeigler, J.M., Tuttle, S.D., Geise, G.S., and Tasha, H.J., 1964, Residence time of sand composing the beaches and bars of outer Cape Cod. in Proceedings of 9th Conference on Coastal Engineering, p. 403-416.

For more information about this or other USGS investigations in Massachusetts, contact the USGS Massachusetts-Rhode Island Water Science Center at 1-508-490-5000 or visit our Web site at http://ma.water.usgs.gov/.

Page 1 photo courtesy of Cape Cod National Seashore. Graphic design by Christine Mendelsohn 